\title{
Progestin Treatment for the Prevention of Preterm Birth
}

\author{
Miha Lucovnik, MD ${ }^{1,2}$, Ruben J. Kuon ${ }^{1,3}$, Linda R. Chambliss, MD, MPH ${ }^{1}$, William L. Maner, \\ BSc, BA ${ }^{1}$, Shao-Qing Shi, MD ${ }^{1}$, Leili Shi, DDS, MS ${ }^{1}$, James Balducci, MD, MBA ${ }^{1}$, and Robert \\ E. Garfield, $\mathrm{PhD}^{1}$ \\ ${ }^{1}$ Department of Obstetrics and Gynecology, St. Joseph's Hospital and Medical Center, Phoenix, \\ Arizona \\ ${ }^{2}$ Department of Obstetrics and Gynecology, Division of Perinatology, University Medical Center \\ Ljubljana, Slovenia \\ ${ }^{3}$ University of Heidelberg, Heidelberg, Germany
}

\begin{abstract}
Progestin supplementation appears to be a promising approach to both preventing initiation of preterm labor and treating it once it is already established, given progesterone's role in maintaining pregnancy as well as support from basic and clinical research. Progesterone and 17alpha-hydroxyprogesterone-acetate (17-OH P) slow the process of cervical ripening and this is the rationale for prophylactic long-term progestin supplementation mostly studied so far. However, progesterone (but not 17-OH P) also inhibits myometrial activity even after the cervix is already ripened. Moreover, these effects depend greatly on the vehicle used and the route of administration. Understanding different mechanisms of action, as well as the importance of progestin formulation, vehicle, and route of administration is the key to finding the optimal progestin treatment for prevention of preterm birth.
\end{abstract}

\section{Keywords}

preterm birth; progesterone; 17 alpha hydroxyprogesterone acetate

\section{Introduction}

Preterm birth remains the biggest unsolved obstetrical problem. As much as $70 \%$ of perinatal mortality is attributed to prematurity, and many of the surviving preterm infants suffer serious lifelong morbidity, including cerebral palsy, blindness, hearing loss, learning disabilities, and other chronic conditions (1-3). In spite of extensive research and a variety of interventions, the incidence of preterm birth has not declined (4).

Most common interventions recommended to prevent preterm birth have been proven to have little or no benefit. Bed rest, once universally advocated, is now largely historical, and cerlage, antibiotics or tocolytics may be beneficial only in specific circumstances (5). Once preterm labor is established, the goal of treatment is merely to delay delivery in order to allow for the transfer of the pregnant patient to the most appropriate hospital and for administration of corticosteroids (6). None of the currently available treatments for preterm labor can prolong pregnancy sufficiently to allow further intrauterine growth and maturation of the fetus (7). There is experimental support from animal and in vitro studies, and also

Corresponding Author: Robert E. Garfield, PhD, St. Joseph's Hospital and Medical Center, Downtown Campus at TGen, 445 N $5^{\text {th }}$ Street, Phoenix, AZ 85004; Tel: (602) 406-8354; Fax: (602) 798-0528; robert.garfield@chw.edu. 
empirical evidence from large randomized placebo-controlled clinical trials, that treatment with progestins (group of steroid hormones that include natural progesterone and its analogues) may reduce the risk of preterm birth. The exact mechanisms of action, optimal progestin formulation, dose, route and timing of administration are, however, still unknown.

\section{Material and methods}

We performed a search in PubMed and Medline to identify publications on progestin treatments for prevention of preterm birth. The search was performed in May 2010 and the following search conditions were used: English language; 1966-2010; search terms: "premature labor" AND ("progestins" OR "progesterone" OR "17 alpha hydroxy progesterone caproate").

\section{Current treatment of preterm labor}

For several decades, stopping uterine contractions, i.e. tocolysis, has been the focus of treating preterm labor. The reason for this is the incorrect assumption that uterine contractions detected by the patient or external tocodynamometry indicate the changes in the myometrium responsible for initiation of labor. Inhibition of contractions should, therefore, prevent preterm delivery and reduce neonatal mortality and morbidity. Unfortunately, however, this is not the case. Neither do clinically used methods to assess uterine contractility detect the molecular changes characteristic of myometrial activation and true labor, nor are tocolytic agents available today able to reverse the mechanisms of labor and allow further intrauterine growth and development of the fetus. These are most probably the main reasons why tocolytics have not been shown to improve neonatal outcome (7).

Nevertheless, tocolytic agents do have an effect on myometrial contractility and should be used until better treatment options become available in preterm labor patients who need to be transferred to a hospital with facilities for neonatal intensive care and in those who have not yet completed a full course of antenatal corticosteroids (7).

Mechanisms of action of tocolytics-Several pharmacologic agents are currently used to achieve tocolysis: beta-adrenergic agonists (such as terbutaline), magnesium sulfate, nitric oxide donors (e.g. nitroglycerin), calcium channel blockers (such as nifedipine), cyclooxygenase inhibitors (such as indomethacin), and oxytocin receptor antagonists (such as atosiban). These agents cause uterine relaxation by several mechanisms: Beta-adrenergic agonists increase the levels of intracellular cyclic adenosine monophosphate (cAMP), which inactivates myosin light-chain kinase and consequently inhibit contractility (8).

Unfortunately, the ability to generate and react to cAMP decreases when the myometrium is preparing for labor (9). Magnesium sulfate hyperpolarizes the plasma membrane, decreases the intracellular concentration of calcium, and inhibits myosin light-chain kinase by competing with intracellular calcium $(10,11)$. Nitric oxide donors accomplish muscle relaxation via an increased production of cyclic guanosine monophosphate (cGMP) that also inactivates myosin light-chain kinase (12). However, like cAMP, the ability to generate and react to cGMP also decreases during labor (9). Calcium channel blockers inhibit the influx of calcium ions through the plasma membrane and the release of intracellular calcium from the sacroplasmatic reticulum, leading to a decrease in calcium-mediated activity of myosin light-chain kinase (13). Cyclooxygenase inhibitors achieve tocolysis by suppression of prostaglandin synthesis. Prostaglandins increase the formation of myometrial gap junctions and increase the intracellular concentration of calcium by raising its transmembrane influx and its release from sarcoplasmatic reticulum (14). And finally, oxytocin receptor antagonists compete with oxytocin for binding to its receptors. Consequently they reduce the oxytocin-mediated conversion of phosphatidylinositol triphosphate to inositol triphosphate which causes the release of calcium from the sarcoplasmatic reticulum (15). 
To summarize, currently used tocolytics inhibit myometrial contractility through altering the intracellular transduction pathways responsible for cell contraction, inhibiting the sythesis of myometrial stimulants, or blocking the actions of myometrial stimulants. None of them, however, can reverse the processes leading to activation of the myometrium during labor at term or preterm.

\section{Use of progestins to prevent preterm birth}

Progesterone has been known to be important in maintaining pregnancy for more than 80 years, since the classic work of Corner, Allen (16) and Csapo (17). A large body of experimental data available today demonstrates that progesterone exerts overall control on both cervical ripening and myometrial contractility. Supplementation of progesterone or its analogues seems, therefore, a very promising strategy for prevention of preterm birth.

Progesterone acts through both genomic and non-genomic pathways $(18,19)$. The classic genomic actions are mediated by the nuclear progesterone receptors that function as ligandactivated transcription factors and modulate the expression of genes associated with maintenance of pregnancy and initiation of labor (20). In contrast to this slow mechanism, the non-genomic actions of progesterone are rapid and directly affect the functions of cells by modulating intracellular signal transduction pathways (18). Different types of progesterone receptors on plasma membrane have been identified recently, and are thought to mediate these rapid actions of progesterone $(18,20,21)$.

Antiprogestins induce ripening of the uterine cervix (22). Therefore, the cascade of events leading to cervical ripening seems to be controlled at least in part by progesterone. In the cervix, progesterone modulates the expression of various genes, including those involved in regulation of epithelial and endothelial permeability and metabolism of components of the extracellular matrix (23). Progesterone also inhibits the ripening process by suppressing the production of proinflammatory cytokines and consequently reducing prostaglandins in the cervix (24). The changes in collagen content in the cervix characteristic for the process of cervical ripening can be assessed non-invasively by measuring the light-induced fluorescence (LIF) of the non-soluble collagen (9). Recently we used cervical LIF to study the effects of progesterone treatment on cervical ripening in rats. Subcutaneous (s.c.) and transdermal administration of progesterone significantly delayed cervical collagen degradation but did not completely suppress ripening (25). S.c. administration of 17 alpha hydroxyprogesterone acetate (17-OH P), a synthetic progestin, also delayed cervical ripening, although less effectively than did progesterone (Figure 1). This is in accordance with the results of some clinical trials (discussed below) that observed an attenuation of cervical shortening measured by ultrasound with intramuscular (i.m.) 17-OH P and vaginal progesterone treatment (26.27).

Progesterone also inhibits myometrial activity by several mechanisms. It suppresses a number of genes that are essential for effective uterine contractions, including genes for the gap junction protein connexin 43 , calcium channels, and oxytocin receptors, etc. (9). It also up-regulates the relaxation mechanisms, such as the generation and action of cAMP and cGMP (14). In addition, progesterone acts by functionally opposing estrogen, which increases myometrial contractility (9). Treatment with onapristone (ZK-98299), a pure antiprogestin, induces preterm delivery and increases the uterine electromyographic (EMG) activity in rats (28) (Figure 2). In vitro studies of human myometrial tissue, demonstrated that progesterone is able to directly suppress contractions and that this effect occurs within 30-60 minutes after addition to the muscle bath, therefore most probably by action on membrane receptors (29). Interestingly, 17-OH P, which is currently the most commonly used synthetic progestin clinically in the prevention of preterm birth, did not suppress myometrial activity (Figure 3 ). This inability of $17-\mathrm{OH} \mathrm{P}$ to inhibit uterine activity has also 
been reported by others (30). Furthermore, although effective in inhibiting cervical ripening, s.c. injections of 17-OH P did not delay delivery, whereas s.c. injections of progesterone completely blocked delivery in rats (25). We conclude that, although partially effective in delaying cervical ripening, 17-OH P has no effect on uterine contractility. In contrast, progesterone is effective in suppressing both cervical ripening and myometrial activity. Moreover, recent studies showed that s.c. progesterone blocked delivery even when administered on day 18 of gestation in rats, i.e. after the cervix is already ripen and the changes in progesterone receptors (described below) have already occurred (25). This demonstrates the crucial role of myometrial inhibition in prevention of preterm delivery. The initiation of human studies on effects of various progestins on uterine EMG activity, will further address the question of myometrial inhibition by progestin treatment.

It should be emphasized that experimental support of the theoretical basis for using progestins to prevent preterm birth is largely based on data from various animal models, which do not entirely resemble the human regarding the role of progesterone in pregnancy. Indeed, as a result of strong evolutionary pressures, physiologic mechanisms that initiate labor vary largely among different species. In most mammals studied, progesterone levels fall before the onset of labor and labor is indeed initiated by this withdrawal of progesterone (31). In humans, however, the opposite occurs: placental progesterone production increases with advancing pregnancy and progesterone levels remain elevated during labor and delivery (32). Similarly, the amount of circulating progesterone is not reduced before the onset of labor in some primates and in guinea pigs (31). Since studies in primates are accompanied by difficulties of ethical and practical nature, guinea pigs have been proposed as the optimal animal model for human parturition. Systemic and intrauterine administration of progesterone and medroxyprogesterone acetate (MPA) did not prolong pregnancy in guinea pigs $(33,34)$. This obviously raises the question whether the effectiveness of progestins in prolongation of pregnancy observed in other mammals is applicable to humans at all. However, intrauterine administration of any drug, regardless of its progestational potential, is likely to precipitate labor in guinea pigs due to their sensitivity to manipulation of the intrauterine environment. What's more, MPA does not seem to be the best candidate for prevention of preterm birth, since it is a relatively low potent progestin, has androgenic properties and was also unsuccessful in clinical trials (see below) $(35,36)$. Most importantly, despite the fact that labor occurs in the face of unchanged or even increasing serum progesterone levels in humans, blockage of progesterone receptors reliably ends human pregnancy $(37,38)$. This suggests that a "functional progesterone withdrawal" may play a role in initiation of parturition in women. There are several proposed mechanisms how this functional withdrawal could be accomplished, including changes in progesterone synthesis and metabolism within the fetal membranes and the decidua, and changes in post receptor mechanisms (39). In addition, changes in expression of progesterone receptors immediately preceding labor have also been demonstrated (18). Receptor changes contributing to the onset of labor have been demonstrated also in species with actual progesterone withdrawal, but treatment with progesterone blocks delivery even after these changes have already occurred $(25,40)$.

Therefore, progestins remain a candidate treatment for the prevention of preterm birth, despite the fact that extrapolating information on actions of progesterone from animal models may not be entirely appropriate. Animal studies also clearly indicate that route of administration and vehicles are important considerations in treatment strategies.

In addition to basic science support for the use of progestins in pregnancy, there is also substantial empirical evidence of their potential benefit from clinical trials. In the last 40 years, progesterone and its analogues have been administered to pregnant women in attempts prevent preterm birth and miscarriage, but with variable success. Comparing these 
studies is extremely difficult because they differ in terms of formulation and dose of progestin used, route of administration, and timing of progestin administration (41). Table 1 summarizes the randomized clinical studies on progestin treatment for prevention of preterm birth published since 2003 .

Formulations of Progestins-Progestins are available as natural (bioidentical, micronized) progesterone and its synthetic analogues. Of the various formulations, only two have generally been considered sufficiently safe and effective to be used for prevention of preterm birth: progesterone and 17-OH P.

Natural (Bioidentical, Micronized) progesterone is manufactured in a laboratory from chemicals derived from plants (Mexican wild yams and soy). It has a molecular structure identical to that of the progesterone produced in humans by the corpus luteum in the luteal phase of the menstrual cycle and during the first trimester of pregnancy and (following the luteal-placental shift) in the largest quantity by the placenta. Micronized progesterone can consequently be referred to as the natural, or the bioidentical, progesterone.

In the randomized clinical trials comparing progesterone to placebo for the prevention of preterm birth, long-term infant outcomes were not evaluated (42-44). However, natural progesterone is FDA-approved to support embryo implantation and early pregnancy, and there have been no significant adverse effects from its use in pregnancy reported to date. It should be noted that progesterone production by the placenta during pregnancy can reach levels of about $500 \mathrm{mg} /$ day at term (45).

The chemical 17-alpha-hydroxyprogesterone caproate (17-OH P) is an artificially made caproate ester of 17-hydroxyprogesterone, a natural progestin produced during pregnancy in much lower quantities than progesterone. It has been developed to produce longer-lasting effects than would be available from progesterone itself (50). The half-life of 17-OH P is approximately 7.8 days, as compared to approximately 35 to 55 hours for progesterone $(45,46)$. Today, $17-\mathrm{OH} \mathrm{P}$ is the most commonly used progestin in the prevention of preterm birth. A survey of maternal-fetal specialists in the United States published in 2006 demonstrated that two-thirds of responding physicians prescribed 17-OH P for patients with a history of prior preterm birth (47).

Physiologically, 17-OH P is thought to have similar effects to that of progesterone. To a certain degree, this assumption is probably correct. For instance, both agents cause a secretory transformation of the endometrium $(48,49)$. However, there are also important physiologic differences that should be considered when deciding which agent to use in the prevention of preterm birth. As mentioned above, our group and others have demonstrated that $17-\mathrm{OH} \mathrm{P}$ does not suppress myometrial contractility, whereas progesterone does $(29,30)$ (Figure 3).

There is evidence suggesting that the use of 17-OH P in pregnancy is safe. In the follow-up of a single randomized trial comparing 17-OH $\mathrm{P}$ to placebo for preventing preterm birth, there were no significant differences in the health and development of children at two years of age (50). However, there are also some data from animal and human studies suggesting that 17-OH P may cause fetal harm by fetal toxicity (not teratogenicity). In mice, there was an increased fetal loss with 17-OH P compared to placebo (51). In rhesus monkeys, total embryo lethality resulted following the administration of $17-\mathrm{OH} \mathrm{P}$ at both $1 \mathrm{X}$ and $10 \mathrm{X}$ the human equivalent dose (52). Moreover, although not significant, there was an increase in intrauterine fetal death among women receiving 17-OH $\mathrm{P}$ compared to placebo in the clinical trial, whose follow-up has been mentioned above (53). An earlier meta-analysis of 17-OH P also showed a possible, again not statistically significant, increase in miscarriage 
with an odds ratio of $1.3(0.61-2.74)$ (54). Further studies are needed in order to evaluate the potentially increased risk of miscarriage and stillbirth associated with the use of 17-OH P. There are also some concerns regarding the vehicle used for 17-OH P injections, namely castor oil. Castor oil was reported to induce labor through release of prostaglandins (55). 17$\mathrm{OH} \mathrm{P}$ is currently FDA pregnancy category D progestin, meaning that the FDA believes there is evidence of fetal harm.

Route of Administration-While 17-OH P is given exclusively i.m., progesterone has been administered by several routes in different studies: orally, i.m. and vaginally. Transdermal supplementation of progesterone to prevent preterm birth has not been studied in humans yet although it is common to use this route for application of steroids in humans.

The main advantage of oral administration of progesterone is its non-invasiveness and consequent acceptability. However, absorption of oral progesterone is quite variable, and it is rapidly metabolized by first-pass effect in the liver, which makes the oral administration essentially ineffective (45). Moreover, side effects such as intrahepatic cholestasis, sleepiness, fatigue, and headaches, are more common when progesterone is given orally $(41,44)$. Three randomized trials to date compared oral progesterone to placebo for prevention of preterm birth. In the studies published in 1986 and 1991, oral progesterone did not prolong gestation in patients treated for preterm labor $(56,57)$. In 2009, in contrast, Rai et al. reported a reduction in preterm delivery in women with a history of preterm birth who received oral progesterone throughout pregnancy compared to placebo (58).

Effectiveness of i.m. injections of progesterone to prevent preterm birth has not been evaluated in clinical trials. The reason for this is that daily i.m. injections would be required to maintain therapeutic serum levels due to the relatively short half- life of progesterone. This would make this intervention very invasive, especially if progesterone was to be given by prolonged prophylactic administration to women at increased risk for preterm birth. 17$\mathrm{OH} \mathrm{P}$ is a long-acting progestin, and can be administered once per week (46). Even with weekly i.m. injections, however, side effects such as injection side pain, swelling, itching, and bruising have been reported in up to one-third of treated women, and were more common in the progestin group as compared to placebo (53).

The vaginal route of progesterone administration has been thought to be the preferred route when focused effects on the uterus are desired. It is non-invasive and the only side effect associated with vaginal progesterone reported in clinical studies was an increased vaginal discharge (44). Following the concept of the liver first-pass effect after administration of oral drugs, the term "uterine first-pass effect" was established in order to point out the minimized systemic, but optimized uterine exposure after vaginal treatment with sex steroids $(59,60)$. De Ziegler et al. observed a 14-fold increase in the ratio of the endometrialto-serum concentrations of progesterone after vaginal (compared to i.m.) administration $(59,60)$. However, these studies were mostly done in postmenopausal women and not during pregnancy. Volume, viscosity and $\mathrm{pH}$ of vaginal fluid and physical properties of vaginal epithelium largely affect the absorption of vaginally administered drugs (61). All of these factors are significantly different in pregnant women as compared to those after menopause.

In addition, the effectiveness of vaginal progesterone seems to depend significantly on the vehicle utilized. Three randomized clinical trials in which progesterone was administered as vaginal suppositories or capsules showed a reduction in preterm delivery $(42,43,62)$. The exact source of progesterone was specified only in one of these three publications. Fonseca et al. used of $200 \mathrm{mg}$ capsules of Utrogestan ${ }^{\circledR}$ (Besins International, Belgium), i.e. progesterone in arachis (peanut) oil and soy lecithin (43). On the other hand, vaginal gel (Crinone ${ }^{\circledR}$, Columbia Laboratories, Inc., Livingston, NJ, USA) containing $90 \mathrm{mg}$ of 
progesterone in a polycarbophil-based vaginal gelReplens ${ }^{\circledR}$ (Columbia Laboratories, Inc., Livingston, NJ, USA), was utilized in the two large studies which reported no benefit from vaginal progesterone $(44,63)$. Vaginal gel is claimed by some to have practical advantages over the capsules or suppositories. It is thought to be easier to apply and it does not liquefy. It is suggested, therefore, that it could cause less vaginal discharge, irritation, and infection. Replens ${ }^{\circledR}$, in particular, is thought to release progesterone slowly, which potentially results in sustained levels of the hormone in the uterus. However, in addition to evidence from clinical studies, our results indicate that progesterone in Replens ${ }^{\circledR}$ may not be as effective as in other vehicles. For example, transdermaly administered progesterone in fish oil delayed delivery in rats, while topical application of progesterone in Replens ${ }^{\circledR}$ did not (25) (Figure 4). This indicates that Replens ${ }^{\circledR}$ does not efficiently release progesterone. Furthermore, measurement of serum progesterone levels supports these conclusions (Figure 5).

More data is needed before any formulation and route of progesterone administration for prevention of preterm birth can be recommended over the others. Our study of various progestin treatments emphasizes this. Only subcutaneous injections of progesterone and transdermal administration of progesterone in fish oil (not in Replens ${ }^{\circledR}$ ) delayed delivery (25) (Figure 4). Notably, none of these routes has been used in clinical trials to date. On the other hand, oral progesterone and vaginal progesterone administration, studied in humans so far, did not have any effect on time of delivery (25). These studies clearly show that in animal models progestins with different properties have varied effects and depend upon the route of administration and vehicle.

Timing of Administration-Another reason why clinical studies of efficacy of progestins in preventing preterm birth are difficult to compare is that participants included were significantly different. The majority of randomized trials evaluated the prophylactic supplementation of progestins in asymptomatic pregnant women at high risk for preterm birth. Women were considered to be at high risk for several reasons, including past history of spontaneous preterm birth or miscarriages, multiple gestation, short cervical length, cerclage in place, and uterine anomalies. Earlier small trials using 17-OH P showed mixed results. Some reported benefit from prophylactic treatment in high-risk singleton pregnancies, whereas 17-OH P injections did not improve outcome in multiple gestations and lower-risk patients (64-68). In 2003, two studies re-invigorated the interest in progestin treatment for prevention of preterm birth. Meis et al. reported results of a large multicenter trial of 17-OH P involving 463 women with a history of spontaneous preterm delivery (53). Delivery at $<37$ weeks was reduced from $55 \%$ in the placebo group to $36 \%$ in the $17-\mathrm{OH} \mathrm{P}$ group. Similar reduction was seen in delivery at $<32$ weeks, from $20 \%$ to $11 \%$. Also in 2003, da Fonseca et al. published a trial of vaginal progesterone vs. placebo suppositories administered to 142 women found to be at high risk due to a history of previous preterm delivery, prophylactic cerclage placed or having a uterine anomaly (42). In $>90 \%$ of participants, the risk factor was previous preterm delivery. The rate of delivery at $<37$ weeks in treated patients was $14 \%$, significantly less that the $29 \%$ observed in the placebo group. Delivery at $<34$ weeks was also lower in the progesterone group (3\%) than in the placebo group (19\%). However, an intervention limited almost exclusively to women who already delivered preterm is unlikely to have a substantial impact on the problem of preterm birth, since only about $10 \%$ of spontaneous preterm births occur in women with such history (69). As a result, further studies were performed to evaluate the use of progestins in pregnant women with other risk factors. Twin pregnancies were the obvious next subject of randomized trials, given the current epidemic of multiple gestations (70). Unfortunately, in 2007 Rouse et al. showed that treatment with 17-OH P did not reduce the rate of preterm births among women with twins, which is in agreement with the results of an earlier study published in $1980(67,71)$. Recently, a large study of 500 women with twin gestation, randomized to receive either vaginal progesterone or placebo, also showed no benefit of 
vaginal progesterone treatment in twin pregnancies (63). Patients who were found to have a short cervix $(<15 \mathrm{~mm})$ measured by transvaginal ultrasound, however, benefited from vaginal progesterone administration (43). Da Fonseca et al. reported a reduction of delivery at $<34$ weeks, from $34 \%$ in the placebo group, to $19 \%$ in the progesterone group. In 2009 , the largest randomized clinical trial of progesterone in prevention of preterm birth to date was published. O'Brien et al. evaluated the effect of vaginal progesterone in women with previous spontaneous preterm birth, and did not find any difference between vaginal progesterone and placebo groups (44). However, further sub-analysis of the data from that same trial was performed by DeFranco et al., which demonstrated that there may be a subset of women with shortened cervical length $(<28 \mathrm{~mm})$ for whom progesterone may have a beneficial effect in prolonging pregnancy (72).

While many studies examined the effects of progestin prophylaxis in pregnancies considered at high risk, there is substantially less data on progestin treatment of patients following acute presentation with signs and symptoms of preterm labor. This is unfortunate, because the majority of patients who deliver preterm do not have any risk factors (73). There are, therefore, many apparently low-risk pregnant women who present acutely in preterm labor, and the use of progestins to prolong pregnancy and improve outcome in these patients has not been studied sufficiently. Between 1960 and 1991, four trials used progestins to stop preterm labor, i.e. as a tocolytic $(35,56,57,74)$. None of these showed any benefit in prolonging pregnancy. Two studies used oral progesterone, one i.m. 17-OH P, and one i.m. MPA. The only other reported use of MPA in humans for prevention of preterm birth was in the study from Hobel et al. in which MPA was also ineffective as prophylactic oral supplementation (36). Thus, it is impossible to generalize the results of the early trials of progestin treatment for preterm labor because of their different designs. In 2007 Fachinetti et al. reported a reduction of risk of preterm birth with the use of 17-OH P as twice weekly i.m. injections in patients treated for preterm labor in which tocolysis was obtained with atosiban (26). The latest study on progesterone use in patients presenting in preterm labor was published in 2008 by Borna et al. They used large doses of vaginal progesterone and showed that progesterone may be beneficial as a maintenance tocolytic, since it prolonged the latency to delivery in the treatment group as compared to patients who received no treatment (62).

To summarize, most clinical studies on progestin treatment for prevention of preterm birth have been accomplished in patients with various risk factors who received prophylactic 17OH P i.m. or progesterone vaginally for several weeks. Since myometrial activation is an acute event, this chronic supplementation of progestins is most likely to affect cervical ripening alone. However, animal studies showed that only minor delay in the cervical changes were observed following 17-OH P or progesterone application (25). Interestingly, progesterone (not 17-OH P) injections completely blocked delivery even after the process of cervical ripening was already completed. The main action must, therefore, be on the myometrium to inhibit labor. The possible benefit of progesterone inhibition of myometrial activity has, however, not been studied sufficiently in humans yet.

\section{Discussion}

Despite extensive research, we are still unable to effectively prevent preterm delivery. There is evidence that supports the use of progestins for reducing the risk of preterm birth. Most of the randomized clinical trials conducted so far have evaluated prophylactic progestin supplementation in asymptomatic women throughout pregnancy. The rationale for this prolonged use is the inhibition of cervical ripening. In fact, the process of gradual remodeling of connective tissue in the cervix begins already in mid-pregnancy and is suppressed at least in part by progesterone and 17-OH P. The use of these two compounds 
has been shown in some trials to be beneficial for preventing preterm birth in patients with certain risk factors, such as previous preterm birth and short cervix.

Myometrial contractility is also suppressed by progesterone (but not 17-OH P). The use of progesterone in patients presenting with signs and symptoms of preterm labor therefore seems promising due to its ability to control both cervical ripening and myometrial activity. The role of progesterone and other progestins in treatment of these patients has, however, not been sufficiently studied yet.

We documented evidence that myometrial activity can be monitored accurately, objectively, and non-invasively by measuring uterine EMG $(75,76)$. This methodology can therefore be extremely useful for obtaining the critically needed comparative data on effectiveness of various progestin formulations and their routes of administration (77).

\section{Abbreviations}

$\begin{array}{ll}\text { cAMP } & \text { cyclic adenosine monophosphate } \\ \text { cGMP } & \text { cyclic guanosine monophosphate } \\ \text { 17-OH P } & 17 \text { alpha hydroxyprogesterone acetate } \\ \text { MPA } & \text { medroxyprogesterone acetate } \\ \text { EMG } & \text { electromyography }\end{array}$

\section{Acknowledgments}

Funded by NIH R01HD037480 and St. Joseph's Foundation, Phoenix, AZ to RE Garfield.

\section{References}

1. Guyer B, Macdorman MF, Martin JA, Peters KD, Strobino DM. Annual summary of vitals statistics - 1997. Pediatrics. 1998; 102(6):1333-1349. [PubMed: 9832567]

2. Marlow N, Wolke D, Bracewell MA, et al. Neurologic and developmental disability at six years of age after extremely preterm birth. N Engl J Med. 2005; 352:9-19. [PubMed: 15635108]

3. Slattery MM, Morison JJ. Preterm delivery. Lancet. 2002; 360:1489-1497. [PubMed: 12433531]

4. Steer M. The epidemiology of preterm labor. BJOG. 2005; 122 Suppl 1:1-3. [PubMed: 15715585]

5. Muglia LJ, Katz M. The enigma of spontaneous preterm birth. N Engl J Med. 2010; 362:529-535. [PubMed: 20147718]

6. Towers CV, Bonebrake R, Padilla G, Rumney P. The effect of transport on the rate of severe intraventricular hemorrhage in very low birth weight infants. Obstet Gynecol. 2000; 95:291-295. [PubMed: 10674596]

7. Gyetvai K, Hannah ME, Hodnett ED, Ohlsson A. Tocolytics for preterm labor: a systematic review. Obstet Gynecol. 1999; 94:869-877. [PubMed: 10546776]

8. Caritis SN, Edelstone DI, Mueller-Heubach E. Pharmacologic inhibition of preterm labor. Am J Obstet Gynecol. 1997; 133:557-578. [PubMed: 35978]

9. Garfield RE, Saade G, Buhimschi C, Buhimschi I, Shi L, Shi SQ, et al. Control and assessment of the uterus and cervix during pregnancy and labour. Hum Reprod Update. 1998; 4:673-695. [PubMed: 10027621]

10. Lemancewivicz A, Laudanska H, Laudanski T, Karpiuk A, Batra S. Permeability of fetal membranes to calcium and magnesium: possible role in preterm labour. Hum Reprod. 2000; 15:2018-2022. [PubMed: 10967007]

11. Mizuki J, Tasaka K, Masumoto N, Kasahara K, Miyake A, Tanizawa O. Magnesium sulfate inhibits oxytocin-induced calcium mobilization in human puerperal myometrial cells: possible 
involvement of intracellular free magnesium concentration. Am J Obstet Gynecol. 1993; 169:134139. [PubMed: 8333439]

12. Ledingham MA, Thomson AJ, Greer IA, Norman JE. Nitric oxide in parturition. BJOG. 2000; 107:581-593. [PubMed: 10826570]

13. Wray S, Jones K, Kupittayanant S, Li Y, Matthew A, Monir-Bisthy E, et al. Calcium signaling and uterine contractility. J Soc Gynecol Investig. 2003; 10:252-264.

14. Challis JR, Sloboda DM, Alfaidy N, Lye SJ, Gibb W, Patel FA, et al. Prostaglandins and mechanisms of preterm birth. Reproduction. 2002; 124:1-17. [PubMed: 12090913]

15. Phaneuf S, Asboth G, MacKenzie IZ, Melin P, Lopez Bernal A. Effect of oxytocin antagonist on the activation of human myometrium in vivo: atosiban prevents oxytocin-induced desensitization. Am J Obstet Gynecol. 1994; 171:1627-1634. [PubMed: 7802080]

16. Allen WM, Corner GW. Physiology of the corpus luteum. VII. Maintenance of pregnancy in rabbit after very early castration by corpus luteum extracts. Proc Soc Exp Biol Med. 1930; 27:403.

17. Csapo IA. Progesterone “block”. Am J Anat. 1956; 98:273-292. [PubMed: 13326855]

18. Mesiano S. Myometrial progesterone responsiveness and the control of human parturition. J Soc Gynecol Investig. 2004; 11(4):193-202.

19. Merlino AA, Welsh TN, Tan H, Yi LJ, Cannon V, Mercer BM, et al. Nuclear progesterone receptors in the human pregnancy myometrium: evidence that parturition involves functional progesterone withdraval mediated by increased expression of progesterone receptor-A. J Clin Endocrinol Metab. 2007; 92(5):1927-1933. [PubMed: 17341556]

20. Sabeur K, Edwards DP, Meizel S. Human sperm plasma membrane progesterone receptor(s) and the acrosome reaction. Biol Reprod. 1996; 54:993-1001. [PubMed: 8722618]

21. Wu, W.; Dong, Y-L.; Balducci, J.; Huang, H.; Garfield, RE. Expression of PGRMC1, a Novel Progesterone Receptor Component in Human Myometrium, is Down Regulated During Labor at Term and Preterm. 57th Annual Scientific Meeting of the Society for Gynecologic Investigation; March 2010; Orlando, FL. \# 320.

22. Chwalisz K. The use of progesterone antagonists for cervical ripening and as an adjunct to labour and delivery. Hum Reprod. 1994; 9 Suppl 1:131-161. [PubMed: 7962460]

23. Xu H, Gonzalez JM, Ofori E, Elovitz MA. Preventing cervical ripening: the primary mechanism by which progestational agents prevent preterm birth? Am J Obstet Gynecol. 2008; 198 314.e1314.e8.

24. Kelly RW. Pregnancy maintenance and parturition: the role of prostaglandin in manipulating the immune and inflammatory response. Endocr Rev. 1994; 15:684-706. [PubMed: 7843072]

25. Kuon RJ, Shi S-Q, Maul H, Sohn C, Balducci J, Maner WL, et al. Pharmacologic actions of progestins to inhibit cervical ripening and prevent delivery depend on their properties, the route of administration, and the vehicle. Am J Obstet Gynecol. 2010; 202(5) 455.e1-455.e9.

26. Facchinetti F, Paganelli S, Comitini G, Dante G, Volpe A. Cervical length changes during preterm cervical ripening: effects of 17-alpha-hydroxyprogesterone caproate. Am J Obstet Gynecol. 2007; $196453 . e 1-4$.

27. O'Brien JM, DeFranco EA, Adair CD, Lewis DF, Halls DR, How H, et al. Effect of progesterone on cervical shortening in women at risk for preterm birth: secondary analysis from a multinational, randomized, double-blind, placebo-controlled trial. Ultrasound Obstet Gynecol. 2009; 34:653659. [PubMed: 19918965]

28. Shi SQ, Maner WL, Mackay LB, Garfield RE. Identification of term and preterm labor in rats using artificial neural networks on uterine electromyography signals. Am J Obstet Gynecol. 2008 Feb.198(2) 235.e1-4.

29. Ruddock N, Shi S-Q, Jain S, Moore G, Hankins GDV, Romero R, Garfield RE. Progesterone, but not 17alpha hydroxyprogesterone caproate, inhibits human myometrial contractions. Am J Obstet Gynecol. 2008; 199 391.e1-7.

30. Sexton DJ, O'Reilly MW, Friel AM, Morrison JJ. Functional effects of 17alphahydroxyprogesterone caproate (17P) on human myometrial contractility in vitro. Reprod Biol Endocrinol. 2004; 2:80. [PubMed: 15585068]

31. Mitchell BF, Taggart MJ. Are animal models relevant to key aspects of human parturition? Am J Physiol Regul Integr Comp Physiol. 2009; 297:R525-R545. [PubMed: 19515978] 
32. Tulchinsky D, Hobel CY, Yeager E, Marshall YR. Plasma estrone, estradiol, estriol, progesterone, and 17alpha-hydroxyprogesterone in human pregnancy. I. Normal pregnancy. Am J Obstet Gynecol. 1972; 112:1095-1100. [PubMed: 5025870]

33. Zarrow MX, Anderson NC, Callantine MR. Failure of progesterone to prolong pregnancy in guinea pig. Nature. 1963; 198:690-692. [PubMed: 14003278]

34. Porter DG. The failure of progesterone to affect myometrial activity in guinea-pig. J Endocr. 1970; 46:425-434. [PubMed: 5443187]

35. Fuchs F, Stakemann G. Treatment of threatened premature labor with large doses of progesterone. Am J Obstet Gynecol. 1960; 79:172-176. [PubMed: 13825506]

36. Hobel CJ, Ross MG, Bemis RL, Bragonier JR, Nessim S, Sandhu S, et al. The West Los Angeles Preterm Birth Prevention Project. I. Program impact on high risk women. Am J Obstet Gynecol. 1994; 170:54-62. [PubMed: 8296845]

37. Neilson JP. Mifepristone for induction of labor. Cochrane Database Syst Rev. 2000 CD002865.

38. Thong KJ, Baird DT. Induction of abortion with mifepristone and misoprostol in early pregnancy. BJOG. 2005; 99(12):1004-1007.

39. Mitchell BF, Mitchell JM, Chowdhury J, Tougas M, Engelen SM, Senff M, et al. Metabolites of progesterone and the pregnane $\mathrm{X}$ receptor: a novel pathway regulating uterine contractility in pregnancy? Am J Obstet Gynecol. 2005:1921304-1921313.

40. Condon JC, Hardy DB, Kovaric K, Mandelson CR. Up-regulation of the progesterone receptor (PR)-C isoform in laboring myometrium by activation of nuclear factor-kB may contribute to the onset of labor through inhibition of PR function. Mol Endocrinol. 2005; 20(4):764-775. [PubMed: 16339279]

41. Rode L, Langhoff-Roos J, Andersson C, Dinesen J, Schou Hammerun M, Mohapeloa H, et al. Systematic review of progesterone for the prevention of preterm birth in singleton pregnancies. Acta Obstet Gynecol Scand. 2009; 88:1180-1189. [PubMed: 19900136]

42. da Fonseca EB, Bittar RE, Carvalho MHB, Zugaib M. Prophylactic administration of progesterone by vaginal suppository to reduce the incidence of spontaneous preterm birth in women at increased risk: A randomized placebo-controlled double-blind study. Am J Obstet Gynecol. 2003; 188:419424. [PubMed: 12592250]

43. Fonseca EB, Celik E, Parra M, Singh M, Nicolaides KH. Progesterone and the risk of preterm birth among women with a short cervix. N Engl J Med. 2007; 357:462-469. [PubMed: 17671254]

44. O'Brien JM, Adair CD, Lewis DF, et al. Progesterone vaginal gel for the reduction of recurrent preterm birth: primary results from a randomized, double-blind, placebo-controlled trial. Ultrasound Obstet Gynecol. 2007; 30:687-696. [PubMed: 17899572]

45. Murray JL. Natural progesterone: what role in women's heatlh care? Women's Health Primary Care. 1998; 1:671-687.

46. Onsrud M, Paus E, Haug E, Kjorstad K. Intramuscular administration of hydroxyprogesterone caproate in patients with endometrial carcinoma. Pharmacocinetics and effects on adrenal function. Acta Obstet Gynecol Scand. 1985; 64:519-523. [PubMed: 2932883]

47. Ness A, Dias T, Damus K, Burd I, Bergella V. Impact of the recent randomized trial on the use of progesterone to prevent preterm birth: a 2005 follow-up survey. Am J Obstet Gynecol. 2005; 195:1174-1179. [PubMed: 17000251]

48. Gibbons WE, Toner JP, Hamacher P, Kolm P. Experience with a novel vaginal progesterone preparation in a donor oocyte program. Fertil Steril. 1998; 69:96-101. [PubMed: 9457941]

49. Tavaniotou A, Smitz J, Bourgain C, Devroey P. Comparrison between different routes of progesterone administration as luteal phase support in infertility treatments. Hum Reprod Update. 2000; 6:139-148. [PubMed: 10782572]

50. Northen AT, Norman GS, Anderson K, Moseley L, Divito M, Cotroneo M, et al. Follow-up of children exposed in utero to 17 alpha-hydroxyprogesterone caproate compared with placebo. Obstet Gynecol. 2007; 110:865-872. [PubMed: 17906021]

51. Seegmiller RE, Nelson GW, Johnson CK. Evaluation of the Teratogenic Potential of Delalutin (17alpha-Hydroxyprogesterone Caproate) in Mice. Teratology. 1983; 28:201-208. [PubMed: 6648824] 
52. Hendrickx AG, Korte R, Leuschner F, Neumann BW, Poggel A, Binkerd P, et al. Embriotoxicity of sex steroidal hormones in nonhuman primates: II. Hydroxyprogesterone caproate, estradiol valerate. Teratology. 1987; 35(1):129. [PubMed: 3563931]

53. Meis PJ, Klebanoff M, Thom E, Dombrowski MP, Sibai B, Moawad AH, et al. Prevention of recurrent preterm delivery by 17 alpha-hydroxyprogesterone caproate. N Engl J Med. 2003; 348:2379-2385. [PubMed: 12802023]

54. Keirse MJNC. Progestogen administration in pregnancy may prevent preterm delivery. BJOG. 1990; 97:149-154.

55. Brancazio LR, Murtha AP, Heine RP. Prevention of recurrent preterm delivery by 17-alphahydroxyprogesterone caproate. N Engl J Med. 2003; 349:1987-1988. [PubMed: 14627782]

56. Erny R, Pigne A, Prouvost C, Gamerre M, Malet C, Serment H, et al. The effects of oral administration of progesterone for premature labor. Am J Obstet Gynecol. 1986; 154(3):525-529. [PubMed: 3513581]

57. Noblot G, Audra P, Dargent D, Faguer B, Mellier G. The use of micronized progesterone in the treatment of menace of preterm delivery. Eur J Obstet Gynecol Reprod Biol. 1991; 40(3):203-209. [PubMed: 1879595]

58. Rai P, Rajaram S, Goel N, Gopalakrishnan RA, Agarwal R, Mehta S. Oral micronized progesterone for prevention of preterm birth. Int J Gynaecol Obstet. 2009; 104:40-43. [PubMed: 18929360]

59. De Ziegler D, Bulletti C, De Monstier B, Jaaskelainen A-S. The first pass uterine effect. Ann N Ann N Y Acad SciY Acad Sci. 1997; 828:291-299.

60. Cicinelli E, Cignarelli M, Sabatelli S, Romano F, Schonauer LM, Padovano R, et al. Plasma concentrations of progesterone are higher in the uterine artery than in the radial artery after vaginal administration of micronized progesterone in an oil-based solution to postmenopausal women. Fertil Steril. 1998; 69:471-473. [PubMed: 9531879]

61. Richardson JL, Illum L. The vaginal route of peptide and protein drug delivery. Adv Drug Deliv Rev. 1992; 8:341-366.

62. Borna S, Sahabi N. Progesterone for maintenance tocolytic therapy after threatened preterm labour: A randomised controlled trial. Aust N Z J Obstet Gynecol. 2008; 48:58-63.

63. Norman JE, Mackenzie F, Owen P, Mactier H, Hanretty K, Cooper S, et al. Progesterone for the prevention of preterm birth in twin pregnancy (STOPPIT): a randomized, double-blind, placebocontrolled study and meta-analysis. Lancet. 2009; 373:2034-2040. [PubMed: 19523680]

64. Papiernik-Berkhauer E. Etude en double aveugle d'un medicament prenvenant la survenue premature de l'accouchement chez les femmes a risqué d'accouchement premature. Edition Shering Serie IV. 1970; 3:65-68.

65. Johnson JW, Lee PA, Zachary AS, Calhoun S, Migeon CJ. High-risk prematurity-progestin treatment and steroid studies. Obstet Gynecol. 1979; 54(4):412-418. [PubMed: 492618]

66. Yemini M, Borenstein R, Dreazen E, Apelman Z, Mogilner BM, Kessler I, et al. Prevention of premature labor by 17 alpha-hydroxyprogesterone caproate. Am J Obstet Gynecol. 1985; 151(5): 574-577. [PubMed: 3976757]

67. Hartikainen-Sorri A-L, Kauppila A, Tuimala R. Inefficacy of 17 alpha-hydroxyprogesterone caproate in the prevention of prematurity in twin pregnancy. Am J Obstet Gynecol. 1980; 56:692695.

68. Hauth JC, Gilstrap LC III, Brekken AL, Hauth JM. The effect of 17 alpha-hydroxyprogesterone caproate on pregnancy outcome in an active-duty military population. Am J Obstet Gynecol. 1983; 146(2):187-190. [PubMed: 6682631]

69. Petrini JR, Callaghan WM, Klebanoff M, Green NS, Lackritz EM, Howse JL, et al. Estimated effect of 17 alpha-hydroxyprogesterone caproate on preterm birth in the United States. Obstet Gynecol. 2005; 105:267-272. [PubMed: 15684150]

70. Greene MF. Progesterone and preterm delivery - déjà vu all over again. N Engl J Med. 2003; 348:24. [PubMed: 12510039]

71. Rouse DJ, Caritis SN, Peaceman AM, Sciscione A, Thom EA, Spong CY, et al. A trial of 17 alphahydroxyprogesterone caproate to prevent prematurity in twins. N Engl J Med. 2007; 357:454-461. [PubMed: 17671253] 
72. DeFranco EA, O'Brien JM, Adair CD, Lewis DF, Hall DR, Fusey S, et al. Vaginal progesterone is associated with a decrease in risk for early preterm birth and improved neonatal outcome in women with a short cervix: A secondary analysis from a randomized, double-blind, placebocontrolled trial. Ultrasound Obstet Gynecol. 2007; 30(5):697-705. [PubMed: 17899571]

73. Iams, JD.; Romero, R. Preterm Birth. In: Gabbe, SG.; Niebyl, JR.; Simpson, JL., editors. Obstetrics: Normal and Problem Pregnancies. 5th edn. Philadelphia PA: Churchill Livingstone Elsevier; 2007. p. 668-712.

74. Kauppila A, Hartikainen-Sorri A-L, Janne O, Tuimala R, Jarvinen PA. Suppression of threatened premature labor by administration of cortisol and 17ahydroxyprogesterone caproate: a comparison with ritodrine. Am J Obstet Gynecol. 1980; 138:404-408. [PubMed: 7424996]

75. Maner, WLGarfield RE.; Maul, H.; Olson, G.; Saade, G. Predicting term and preterm delivery with transabdominal uterine electromyography. Obstet Gynecol. 2003; 101:1254-1260. [PubMed: 12798533]

76. Lucovnik M, Maner WL, Chambliss LR, Blumrick R, Balducci J, Novak-Antolic Z, et al. Noninvasive uterine electromyography for prediction of preterm delivery. Am J Obstet Gynecol. 2010 (in press).

77. Lucovnik M, Kuon RJ, Chambliss LR, Maner WL, Shi S-Q, Shi L, et al. Use of uterine electromyography to diagnose term and preterm labor. Acta Obstet Gynecol Scand. 2010 (in press). 


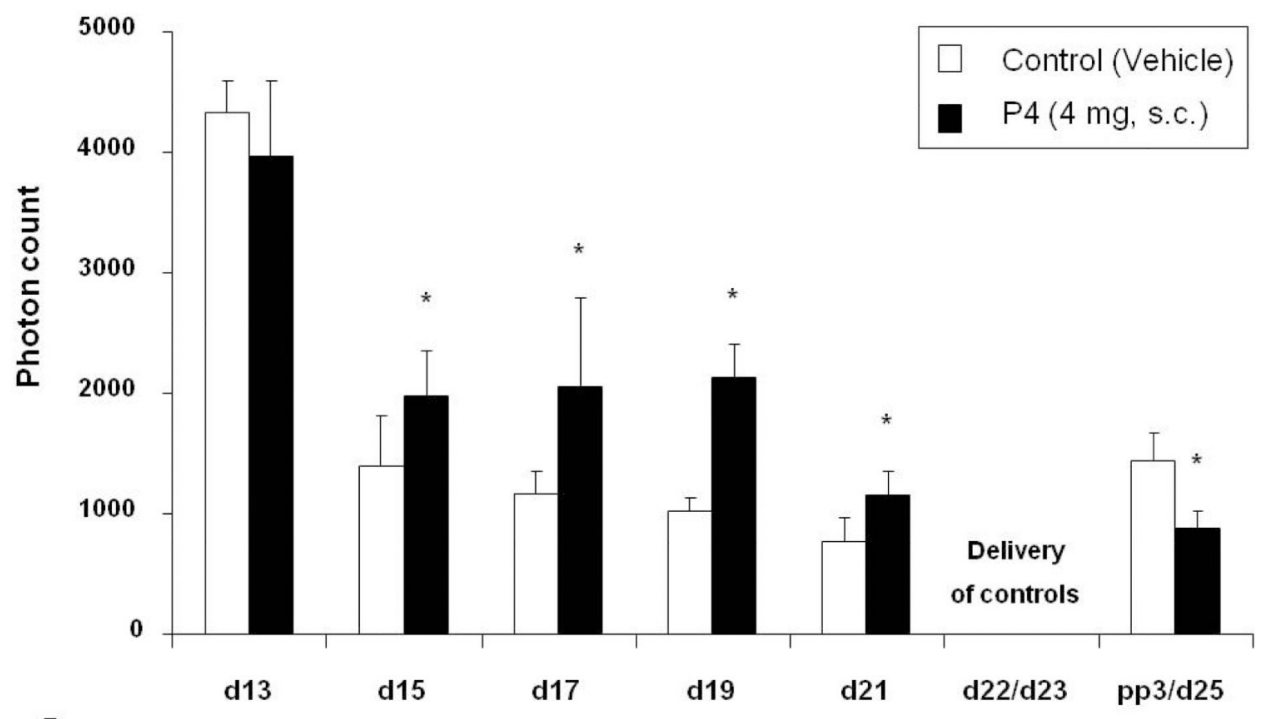

A

Day of pregnancy and postpartum

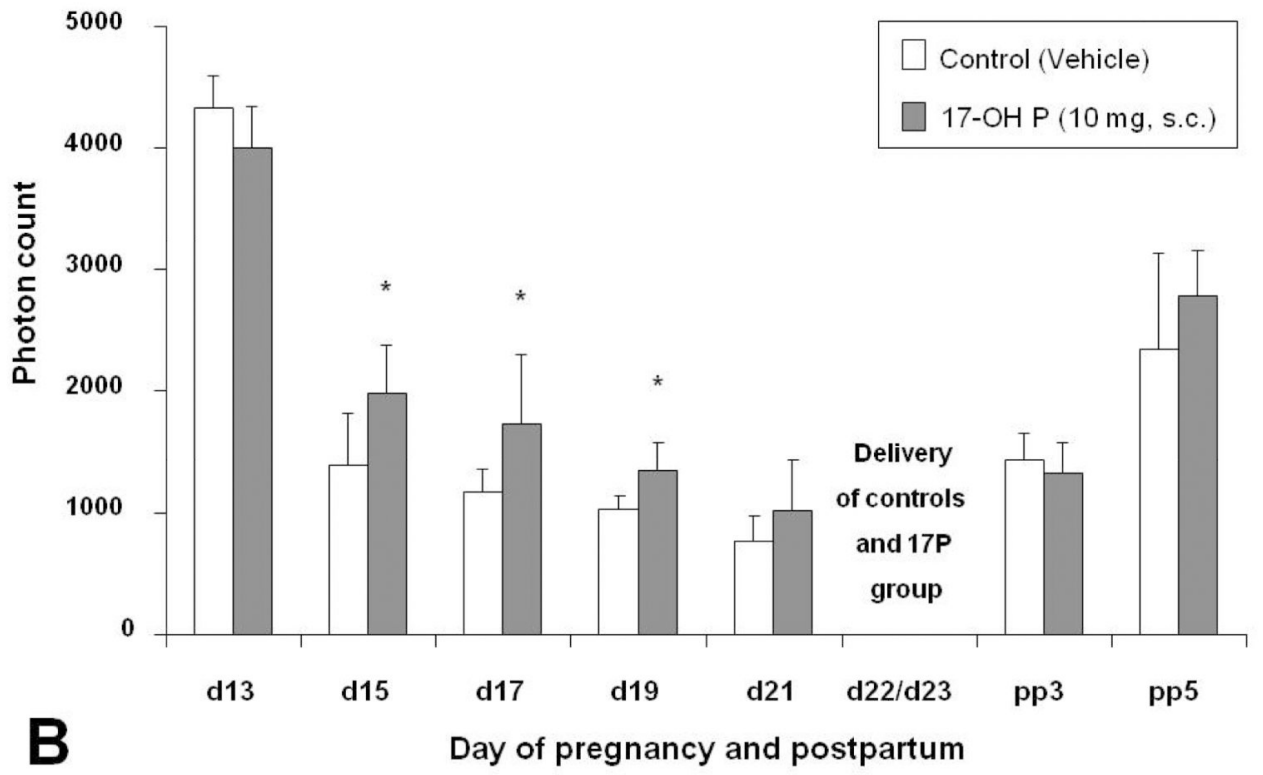

Figure 1.

Bar graphs showing means \pm SD of cervical light-induced fluorescence (LIF) obtained in vivo from pregnant rats at different days of pregnancy and postpartum treated with progesterone (P4), 17-OH P, or vehicle. A) Daily treatment with vehicle (controls) or P4 (4 $\mathrm{mg}$, s.c.). Note that delivery is inhibited in the treatment group. B) Treatment daily with vehicle (controls) or 17-OH P (10 mg, s.c.). Note that significant differences are only observed until day 19 of gestation. From Kuon et. al. Am J Obstet Gynecol. 2010;202:455 e1-9. 


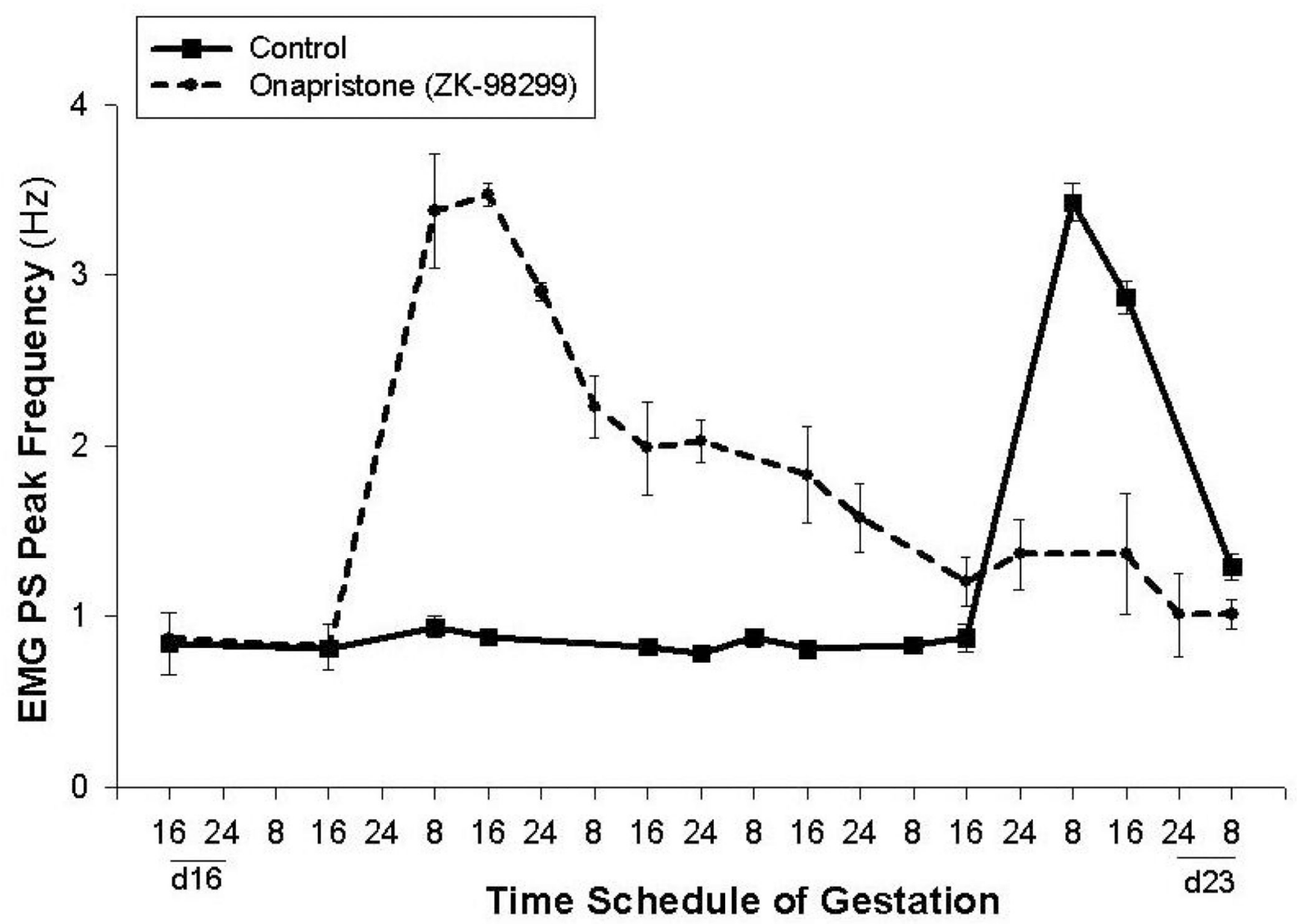

Figure 2.

Treatment with onapristone (ZK-98299) on day 16 of pregnancy induces preterm delivery and an increase the EMG PS Peak frequency in rats. From modification of figures in Shi et. al. Am J. Obstet Gynecol. 2008;198:235 e1-235.e4. 


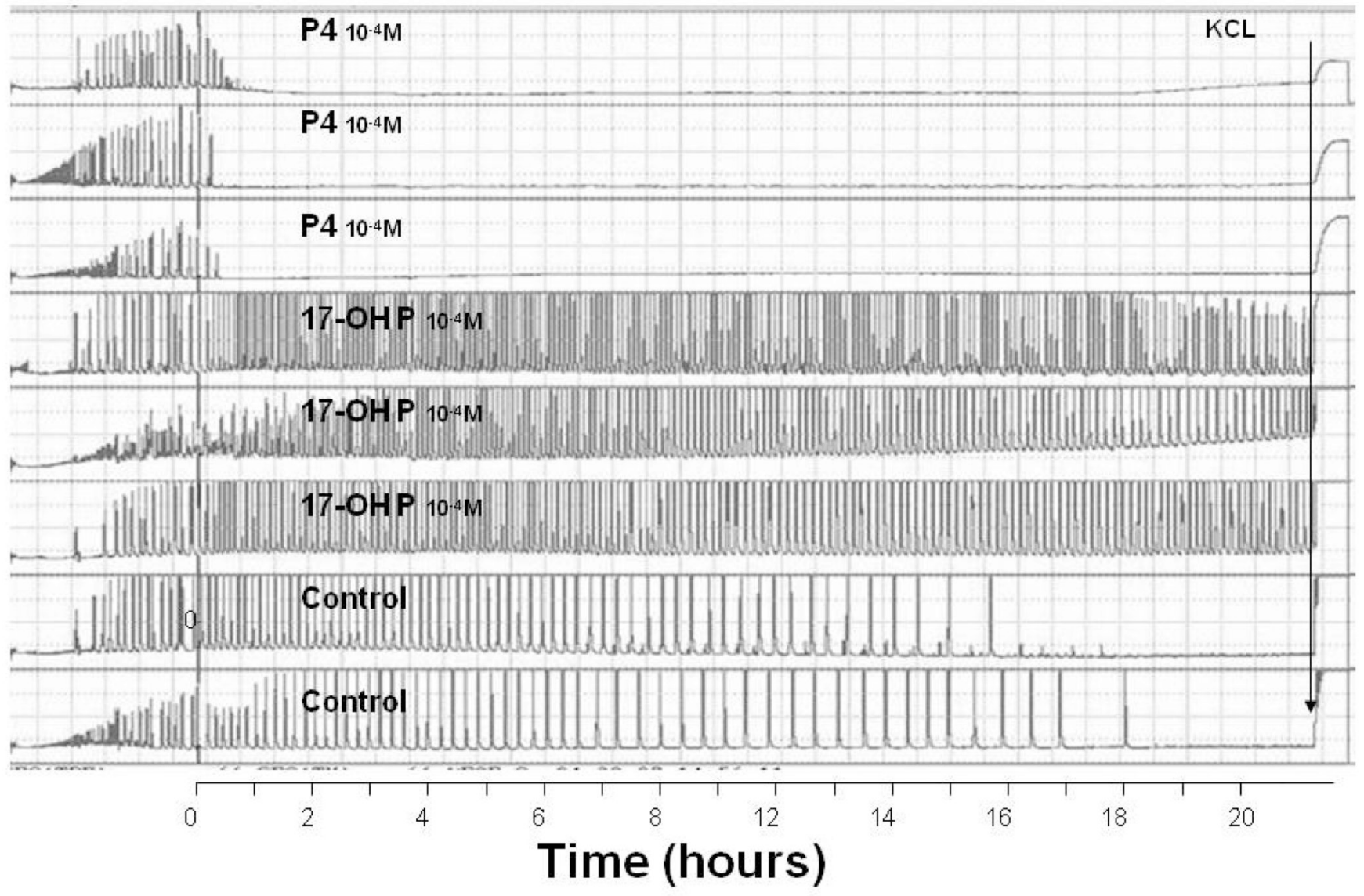

Figure 3.

The effects of progesterone ( $\mathrm{P} 4)$ (top 3 traces) and 17-OH $\mathrm{P}$ (traces 4 to 6 from top) on myometrial contractility. $\mathrm{KCl}$ was added to the baths just prior to termination of the experiment. Note the inhibition of myometrial contractility with P4, but not with 17-OH P. From Ruddock et al. Am J Obstet Gynecol 2008;199:391.e1-391.e7. 


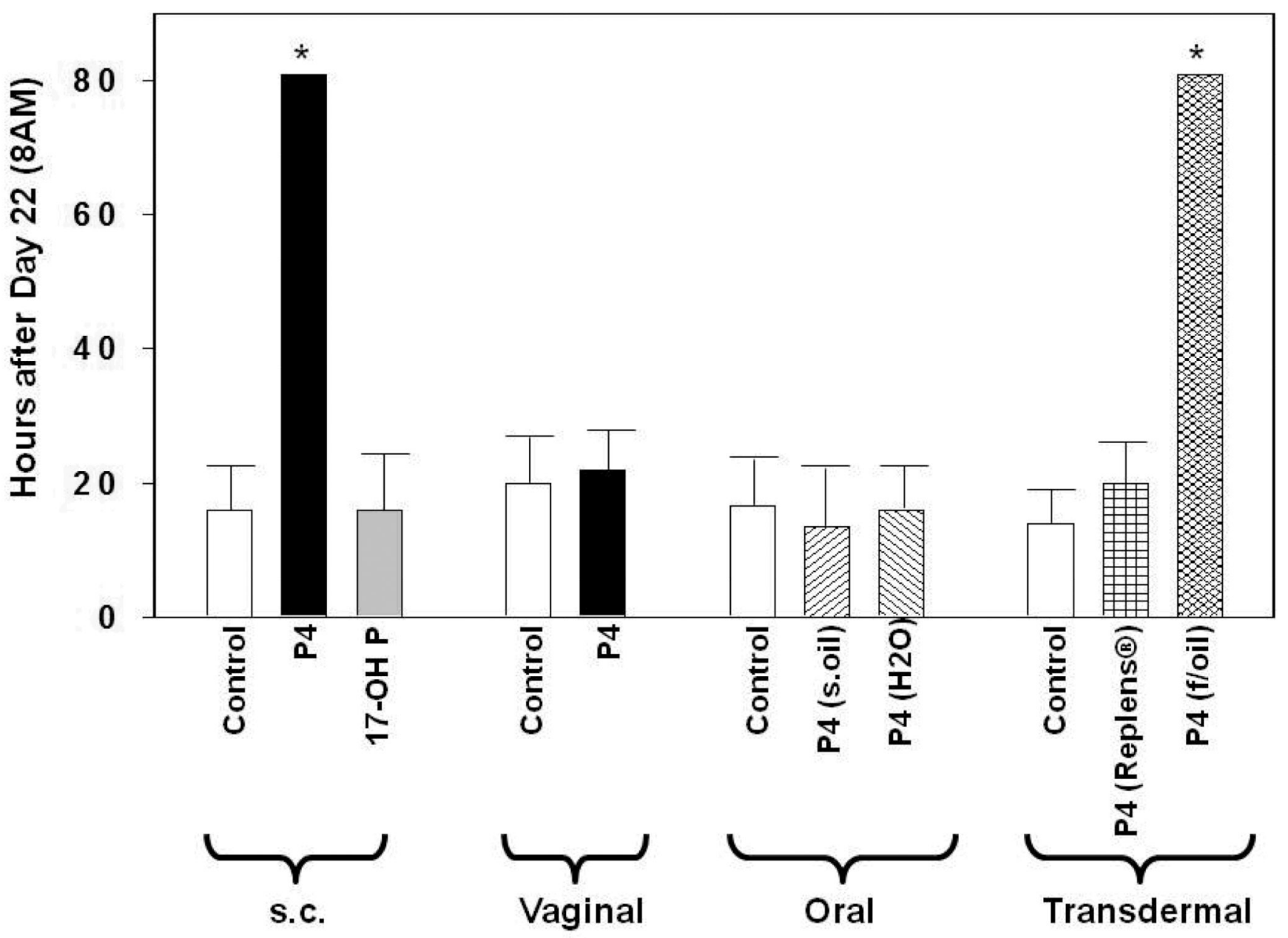

Figure 4.

Shown is the time of delivery (= hours after 8 a.m. of day 22 of gestation) of pregnant rats treated with vehicles (controls) and progestins by different routes of administration injections (s.c.; daily): vehicle: sesame oil; progesterone (P4) (4 mg); 17-OH P (10 mg); vaginal (bid): vehicle: Replens ${ }^{\circledR}$; P4 (15 mg, Crinone $\left.{ }^{\circledR}\right)$; oral (bid): vehicle: sesame oil or $\mathrm{H}_{2} \mathrm{O}$; P4 (15 mg); transdermal (bid): vehicle: Replens ${ }^{\circledR}$ or fish oil; P4 (15 mg). Rats with delayed parturition were sacrificed on day 25 . Asterisks indicate $\mathrm{P}<0.05$ compared with controls. From Kuon et. al. Am J Obstet Gynecol. 2010;202:455 e1-9. 


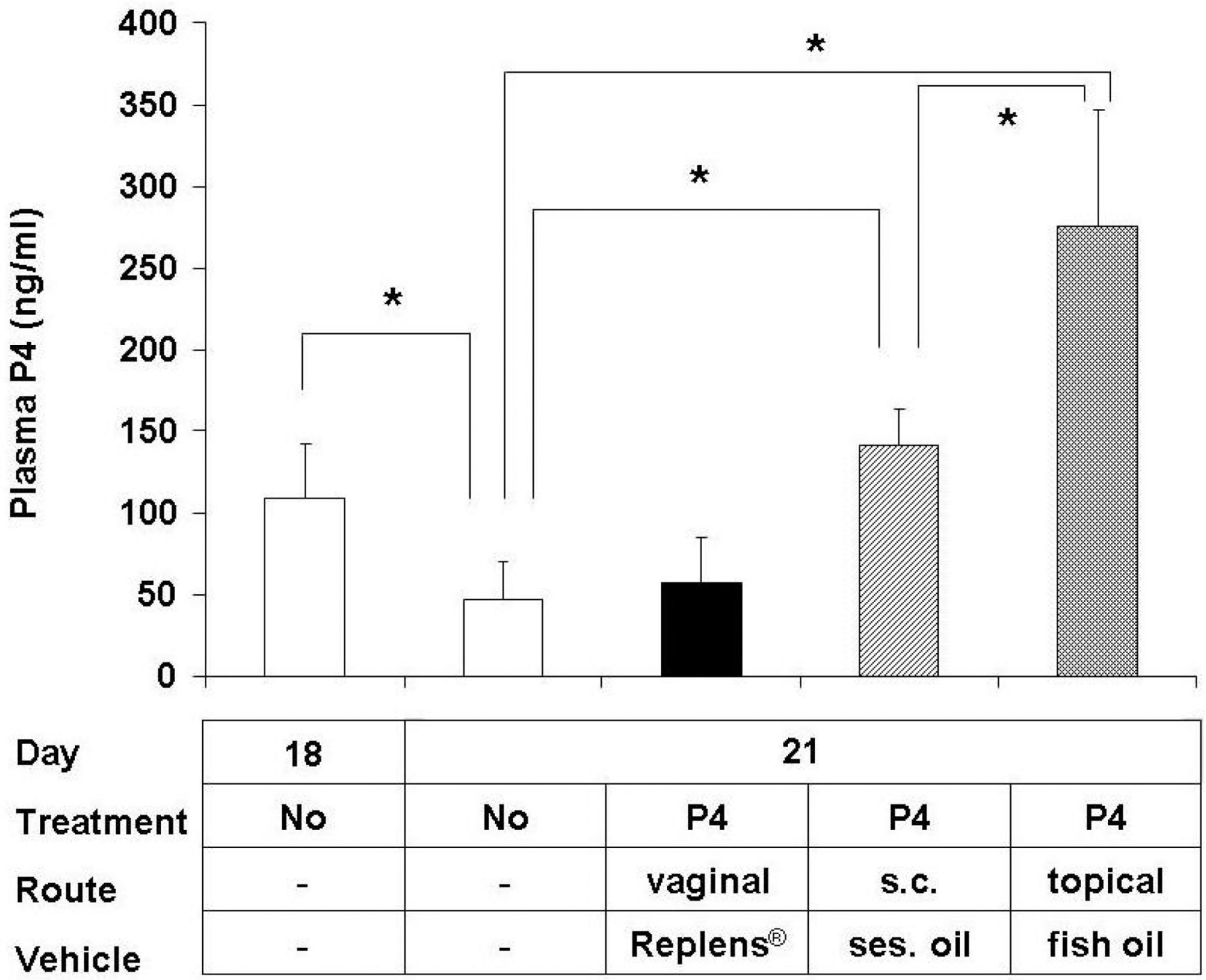

Figure 5 .

Plasma progesterone (P4) levels in pregnant rats on day 18 and 21 without any treatment (controls) and on day 21 after treatment from day 18 until delivery with vaginal P4 (15 mg, bid), s.c. injections of P4 (4 mg), topical P4 in fish oil (15 mg, bid). Asterisks indicate P $<0.05$ compared with controls. Note the physiological P4 withdrawal from day 18 to day 21 in non-treated rats, that is prevented by s.c. and topical P4, but not by vaginal P4. From Kuon et. al. Am J Obstet Gynecol. 2010;202:455 e1-9. 
$\frac{s}{\frac{0}{0}}$

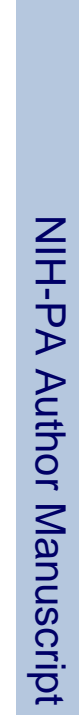

$\vec{s}$

路

乙.

के

$\longrightarrow$

$\Sigma$

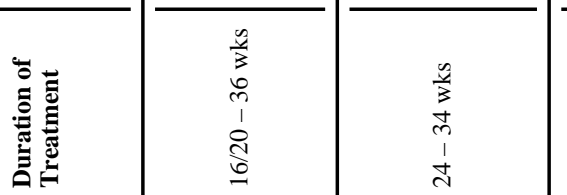

$\Sigma$

焉

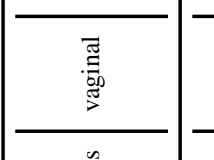

$\frac{n}{3}$
$n$
$n$

กิ

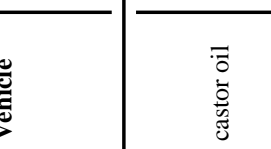

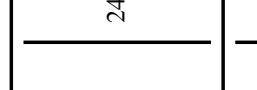

ํํำ

$\frac{4}{3}$

言

这 苟 은

I

굴

$\begin{array}{ll}\frac{1}{1} & \frac{2}{3} \\ 1 & 0\end{array}$

\begin{tabular}{|c|c|c|c|c|c|c|c|c|}
\hline$\overline{\bar{z}}$ & \& & I & $\overrightarrow{ర ్}$ & ฟู & हे & 8 & 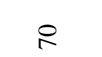 & $\stackrel{n}{n}$ \\
\hline 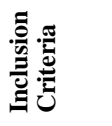 & 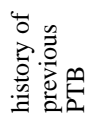 & 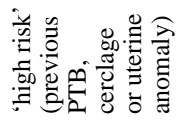 & 吾 & 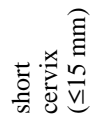 & 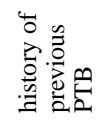 & 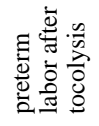 & 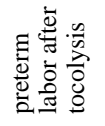 & 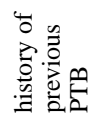 \\
\hline 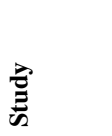 & 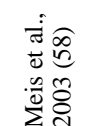 & 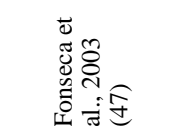 & 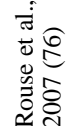 & 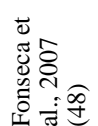 & 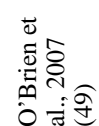 & 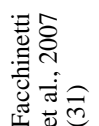 & 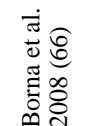 & 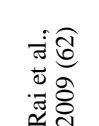 \\
\hline
\end{tabular}




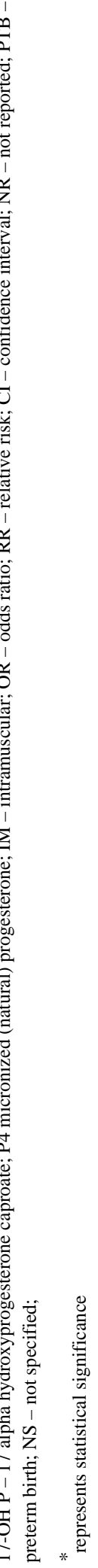

